\title{
The COSMUS Expedition: Seafloor Images and acoustic bathymetric data from the PS124 expedition to the southern Weddell Sea, Antarctica
}

Autun Purser ${ }^{1}$, Laura Hehemann ${ }^{1}$, Lilian Boehringer ${ }^{1}$, Ellen Werner ${ }^{2}$, Santiago E.A. Pineda-Metz ${ }^{1}$, Lucie 5 Vignes $^{3}$, Axel Nordhausen ${ }^{4}$, Moritz Holtappels ${ }^{1}$, Frank Wenzhoefer ${ }^{1,4}$

\author{
${ }^{1}$ Alfred Wegener Institute, Helmholtz Centre for Polar and Marine Research, 27570 Bremerhaven, Germany \\ ${ }^{2}$ HafenCity University Hamburg, Henning-Voscherau-Platz 1, 20457 Hamburg, Germany \\ ${ }^{3}$ Sorbonne Université, CNRS/IRD/MNHN, LOCEAN, IPSL, France, Paris, France \\ ${ }^{4}$ Max Planck Institute of Marine Microbiology, Celsiusstraße 1, 28359 Bremen, Germany
}

10

Correspondence to: Autun Purser (autun.purser@awi.de)

\begin{abstract}
.
Between $3^{\text {rd }}$ February and $30^{\text {th }}$ March 2021 the research icebreaker RV Polarstern conducted an extensive multidisciplinary research expedition across the southern Weddell Sea, Antarctica. During the Continental Shelf Multidisciplinary Flux Study

15 (COSMUS) expedition (designated research expedition PS124) the Ocean Floor Observation and Bathymetry System (OFOBS) was deployed 20 times to collect high resolution seafloor image and acoustic data with a 26-megapixel resolution camera, HD (high definition) video camera, forward facing acoustic camera and multibeam side-scan system from heights of between 1.5 and $4.5 \mathrm{~m}$ above seafloor. To localise the collected data the OFOBS was equipped with a Posidonia transponder for ultra- short baseline position triangulation, an Inertial Navigation System (INS) and a seafloor tracking Dynamic Velocity

20 Logger (DVL). The 20 deployments were made across contrasting areas of the Weddell Sea, Filchner Trough, Filchner Sill and Filchner Shelf. Here, we present the full image data set collected from across the various deployments, as well as raw sidescan data, and derived high resolution bathymetric maps produced from this acoustic data after the cruise.
\end{abstract}

All images are available from: https://doi.pangaea.de/10.1594/PANGAEA.936205 (Purser et al., 2021b) and

25 https://doi.pangaea.de/10.1594/PANGAEA.932827 (Purser et al., 2021c). Acoustic data for all deployments is also available from PANGAEA, with the raw side scan data available at: https://doi.pangaea.de/10.1594/PANGAEA.939322 (Hehemann et al., 2021b), forward facing acoustic camera data at: https://doi.pangaea.de/10.1594/PANGAEA.939341 (Purser et al., 2021a). Seafloor topographic maps derived from the side scan data are available at: https://doi.pangaea.de/10.1594/PANGAEA.939087 (Hehemann et al., 2021a). 
https://doi.org/10.5194/essd-2021-444

Preprint. Discussion started: 28 February 2022

(c) Author(s) 2022. CC BY 4.0 License.

\section{Introduction}

During February and March 2021, the research icebreaker RV Polarstern (Knust, 2017) conducted an extensive multidisciplinary study of the southern Weddell Sea (WS), with the Continental Shelf Multidisciplinary Flux Study (COSMUS) expedition, PS124 (Hellmer and Holtappels, 2021). During the expedition, an interdisciplinary team of researchers investigated ocean heat and mass transport, nutrient dynamics, biological abundance, fauna distribution and seafloor topography across the region of shelf / deep water interface between the deep Weddell Sea, and the shallower Filcher Sill and Filchner Trough regions of the Antarctic continental shelf, north of the Ronne Shelf (Janout et al., 2021; Hattermann et al., 2021). One component of this expedition was the investigation of the seafloor with an advanced towed research platform, the Ocean Floor Observation and Bathymetry System (OFOBS), Figure 1 (Purser et al., 2019b). When deployed, the OFOBS is towed behind a research vessel to collect still images, video, high resolution multibeam side scan and forward-facing acoustic camera data from the seafloor. Commonly deployed at heights of $1.5-2.5 \mathrm{~m}$ above the seafloor, the OFOBS is capable of concurrently collecting still images within which fauna of $>1 \mathrm{~cm}$ diameter can be identified whilst also collecting acoustic data suitable for generating high resolution topographical maps of the seafloor for regions of approximately $50 \mathrm{~m}$ on either side of the device. At time of writing, the OFOBS is the most advanced towed system used in the deep or under ice marine environments by the Alfred Wegener Helmholtz Institute for Polar and Marine Science (AWI), replacing the Ocean Floor Observation System (OFOS), a towed camera platform used until the mid-2010's for Antarctic seafloor surveys, e.g. PS81 and PS96 (Piepenburg et al., 2017). In the western Weddell Sea, PS118 was the first expedition to use the OFOBS in Antarctic waters (Purser et al., 2021d). By keeping the same 26 megapixel camera mounted on the OFOBS as was used on the OFOS, as well as the same illumination sources and deployment methodologies, temporal comparisons of seafloor communities and physical conditions can be made directly between data collected in different years, avoiding inter-comparability problems associated with varying these parameters (Schoening et al., 2020; Jaffe, 2015). As noted in (Pineda-Metz and Gerdes, 2018), fauna analysis of a region is most completely approached by sampling stations with both camera equipment and physical sampling methodologies, such as box, multibox- and multi-corer. During the PS124 expedition a multibox corer (Gerdes, 1990) was also used to sample the surface and infauna megafauna directly, with multicorers also being deployed to allow analysis of the micro and meio-infauna (Hellmer and Holtappels, 2021).

In this data set we present the seafloor still image and acoustic data collected from the OFOBS device during 20 deployments in the WS (Table 1). This data is envisioned as of use for a range of scientific studies, such as:

1) Assessing the seafloor community structures across various contrasting regions of the Weddell Sea seafloor, including those associated with the upwelling warm waters from the deep Weddell Sea onto the continental shelf, as well as the cold, downwelling waters associated with some of the shelf canyon systems.

2) Facilitating a temporal comparison of fauna with images collected during previous expeditions to the area. 
3) Assisting the generation of high-resolution seafloor topographical maps of the Weddell Sea. This data is the first extended side scan survey of many areas of the southern Weddell Sea and Filchner Trough and will likely be usefully integrated into the next iteration of Southern Ocean bathymetric chart (Arndt et al., 2013).

4) Supporting the planning of Marine Protected Areas (MPAs) in Antarctic waters, the data presented here is of the highest spatial resolution yet collected from the area, highlighting the high heterogeneity and high biomasses associated with some of the regions of seafloor surveyed.

\section{Materials and methods}

\subsection{Ocean Floor Observation and Bathymetry System (OFOBS)}

The OFOBS is the current iteration of towed seafloor survey device (Purser et al., 2019b) routinely deployed by the Deep-Sea Ecology and Technology group of the AWI for benthic polar research in under-ice environments (Boetius and Purser, 2017; Morganti et al., 2021; Purser et al., 2021d). The OFOBS is a benthic sled system which is towed behind a research vessel to

75 visually and acoustically investigate the seafloor. During the PS124 expedition, the OFOBS was deployed 20 times. To ensure that the acoustic and illumination systems mounted on the OFOBS did not interfere with the activities of cetaceans, a two person 'whale watch' was maintained on the bridge of $R V$ Polarstern throughout each deployment, and acoustic systems (positioning, side scan and forward-facing acoustic cameras) were only powered up $\sim 50 \mathrm{~m}$ above the seafloor. Throughout the deployments, illumination, flight heights and tow velocities were comparable to those used for the 2020 deployment in the

80 western Weddell Sea (Expedition PS118, (Purser et al., 2021d)). The previous towed benthic survey device used in the area, the Ocean Floor Observation System (OFOS) mounted the same camera systems, was flown with the same illumination, flight height and tow velocities (PS86 in 2015 and PS96 in 2016, (Piepenburg et al., 2017)). Throughout the deployments, the latitude, longitude and depth of the OFOBS was determined via the integration of the iXBlue Posidonia ultra-short base line (USBL) system used by RV Polarstern, localising the relative position of the OFOBS to the vessel (itself deriving its position from the

85 ships satellite based global navigation satellite system (GNSS)). For improving the accuracy of the system positioning for collection of smooth acoustic data, the OFOBS integrated ixBLUE inertial navigation system (INS) and dynamic velocity logger (DVL), further refined the positioning of the system. For the collected image data the Posidonia positions at time of image collection were logged for each image. During the expedition there were occasional problems with the Posidonia system, and where there were gaps in position updates coincident with image collection, a position was estimated from the preceding and subsequent position fixes was assigned. During PS124, an accuracy of position assumed to be $0.2 \%$ of the slanted cable tether length was estimated, or for the majority of deployments made during PS124, of $\sim 30 \mathrm{~m}$ throughout. The start and end positions of each deployment are given in Table 1, with the position fix for each image provided in the data uploaded to PANGEA. 
95 Throughout all deployments, a still image camera, a high-resolution video camera, a forward-facing acoustic camera and a multibeam side scan system collected data concurrently from the seafloor. Each of these systems are introduced in more detail in subsections 2.1.1-2.1.4.

To allow visual seafloor coverage estimations to be made for the areas covered by each image or video frame, three red sizing lasers (FLEXPOINT) were mounted vertically on the OFOBS frame, pointing perpendicularly, and with a $50 \mathrm{~cm}$ spacing (Purser et al., 2019b). For the majority of deployments during PS124, 4-6 $\mathrm{m}^{2}$ of seafloor was imaged in each photograph. The OFOBS was generally towed at a speed of $0.5 \mathrm{kts}$ at a height of $1.5-2 \mathrm{~m}$ above the seafloor. For Stations PS124_54-1, PS124_63-1, PS124_67-1 and PS124_101-1, seafloor coverage per image was 15-25 $\mathrm{m}^{2}$, as for these deployments a higher flight altitude of $2.5-4.5 \mathrm{~m}$ was maintained, as well as a faster towing velocity of $1.5 \mathrm{kts}$.

Throughout all deployments illumination of the seafloor was provided by four downward facing LED lights (SeaLight Sphere 3150), mounted on the corners of the OFOBS frame. Two additional strobe lights (iSiTEC UW-Blitz 250) were through the lens (TTL) triggered light sources that additionally fired when images were collected. The standard LED lights were sufficient to illuminate the seafloor for the HD video recorder also operating throughout each deployment (iSiTEC, Sony FCB-H11).

110 For a full technical description of the OFOBS see (Purser et al., 2019b).

\subsubsection{Still image data collection}

Still images were collected with a 26 megapixel still camera system (iSiTEC, Canon EOS 5D Mark 3). Images were collected at automated 20 second intervals throughout each deployment, though additional 'hotkey' images could be taken to record features of interest, such as the first observations of particular fauna, items of litter or geological features. Within the data set,

115 images taken by the timer were designated with the prefix 'TIMER', whereas those taken manually by the OFOBS operations team were designated with the prefix 'SW_RELEASER' or 'HOTKEY'. No pre-processing stages were applied to the maximum resolution .jpeg data collected from the camera, which are provided here at maximum acquired resolution. The data collected during PS124 complements data collected from the same or stations in close proximity during Antarctic cruises over the last two decades, as a time series survey (i.e. (Piepenburg et al., 2017)), as well as representing the first image based

120 surveys of some areas of the Weddell Sea, such as the area covered by an active Neopagetopsis ionah breeding colony (Purser et al, in revision).

\subsubsection{Video image data collection}

Throughout all deployments, HD (high-definition) video data were recorded by the OFOBS for the duration of each dive with an HD video recorder (iSiTEC, Sony FCB-H11). Unfortunately, during PS124 problems with communication with the camera

125 resulted in fragmented video files and occasional gaps in video data collection. Despite the breakup in the video data, the collected fragments may be used for the 3D 'Structure from Motion' reconstruction of areas of high resolution seafloor 
https://doi.org/10.5194/essd-2021-444

Preprint. Discussion started: 28 February 2022

(c) Author(s) 2022. CC BY 4.0 License.

(c) (i)

topography, an approach which has recently been used with OFOBS data to demonstrate the movement of Arctic sponges (Morganti et al., 2021) and the interactions of deep diving whales with the deep sea seafloor (Purser et al., 2019a).

\section{$130 \quad$ 2.1.3 Forward acoustic camera data collection}

The OFOBS mounts a forward-facing acoustic camera which allows the OFOBS operator to be aware of steep structures or a rising seafloor approaching the platform as it is towed forward through the water, allowing ample time to winch the system to a safer height. During PS124, a BlueView M900-130 acoustic camera was mounted for this purpose, mounted at a $5^{\circ}$ angle at the front of the OFOBS frame. Data is recorded routinely throughout all OFOBS deployments from this system, but is often of little scientific value for benthic surveys, with more scientific work being carried out in the water column and relating to fish distributions and behaviour (Wolff and Badri-Hoeher, 2014). However, as discussed in sections 2.2.1 and 2.2.4, during PS124 the forward acoustic camera also collected data of scientific worth, illuminating aspects of seafloor structure and fauna use not immediately apparent from still or video image data. All data collected with this sensor during PS124 is provided within this data set.

\subsubsection{Side scan data collection and bathymetric map production}

The side scan bathymetry sonar mounted on the OFOBS was an interferometric EdgeTech 2205 AUV/ROV MPES (multiphase echosounder) with two side scan frequencies (low/LF: $230 \mathrm{kHz}$ and high/HF: $540 \mathrm{kHz}$ ). Both frequencies operate in parallel. Integrated into the transducers were receive arrays to allow calculation of 2.5D data per ping ( $3.5 \mathrm{~Hz}$ for $\mathrm{LF}, 7 \mathrm{~Hz}$ for $\mathrm{HF}$ ). On collection, the OFOBS operators could inspect the raw data via a waterfall response display on the ship (Figure 3b). Data was collected and recorded as both raw data and stave data. This data can then be used, in combination with the OFOBS positioning information, to generate 10 and $20 \mathrm{~cm}$ resolution topographic maps of the swathes of seafloor passed over by the OFOBS during deployments. The low deployment height of the side scan system allows small surface depressions and features of a few $10 \mathrm{~s}$ of $\mathrm{cm}$ height to be visible in the derived mapping products, to elucidate aspects of seafloor structure and fauna interactions with the seafloor on a high resolution (Purser et al., 2019a; Marsh et al., 2018). Maps at 10 and $20 \mathrm{~cm}$ resolution have been produced for all station deployments, and form part of this data set.

\subsubsection{Weddell Sea Shelf}

Three OFOBS deployments were made on the Weddell Sea Shelf slope (WSS) (Table 1, Figure 2), deployments PS124_451, PS124_46-3 and PS124_47-2. Deployments were made at several depths from $1188 \mathrm{~m}$ to $1785 \mathrm{~m}$, on the continental shelf

155 slope running from the Filchner Shelf in the south downward toward the north. All deployments were made $5-10 \mathrm{~nm}$ east of a ridge structure (Figure 2). Throughout the deployments clear ripple structures were abundantly clear within many still seafloor images (Figure 4a, c, $\mathbf{d}$ ). A complex interaction between flow regimes, in direction and flow velocities is recorded in 
https://doi.org/10.5194/essd-2021-444

Preprint. Discussion started: 28 February 2022

(c) Author(s) 2022. CC BY 4.0 License.

(c) (i)

the pattern of cross-cutting ripple structures, seeming to indicate changing prevalent flow directions over time (Figure 4d). Some areas of seafloor consisted of gravel and occasional small pebbles, poorly sorted, though these were often overlaid with finer sediments with clear rippling, probably migrating finer sediment deposits, indicating also a temporal variability in flow velocities (Figure 4a). Occasional areas of seafloor showed no clear flow structures, with a fine sediment structure and clear indications of fauna reworking the sediments with surface expressions of burrows clearly visible, such as those occupied by shrimp in Figure 4b. The intermixed rippled beds and occasional larger, angular grit provided physical traps within which or onto which fibrous transported material carried by currents from the shelf and settling through the water column had become entrapped (Figure 4a and 4d), as a potential food source for benthic fauna (Jansen et al., 2018). This entrapped material was associated with higher ophiuroid (Figure 4a) or urchin (Figure 4d) abundances. The side scan data collected from the shelf illuminates the larger sedimentary structures across this region clearly.

\subsubsection{Western Filchner Shelf}

One OFOBS deployment was made on the Western Filchner Shelf (WFS) (Table 1, Figure 2), deployment PS124_37-6. This station, $20 \mathrm{~nm}$ south of the shallowest, most northerly station surveyed on the Weddell Sea shelf (see section 2.2.1) was quite distinctive in seafloor appearance. The great majority of images collected from the sea floor showed a flat seafloor surface, scattered with very many dead barnacle remains (Figure 5a, 5b and 5c). Where accumulations of fragments were highest, epifauna establishment on these biogenic hard surfaces was not uncommon, with soft corals (Figure 5a) and sponges (Figure 5c) both utilising this habitat niche resource, closely resembling the outer slope community described for the region by (PinedaMetz et al., 2019). Mobile fauna, such as octopi and crinoids (Figure 5a), starfish (Figure 5b) and fish (Figure 5c) were observed amongst the fragments. Very occasionally, circular fish nest depressions were observed, though these were far less abundant than observed in the northern Filchner Trough station data (see section 2.2.4), and no eggs were observed. Several iceberg scoured areas were covered by the OFOBS transect (Figure 5d).

\subsubsection{Eastern Filchner Shelf}

Four OFOBS deployments were made on the Eastern Filchner Shelf (EFS) (Table 1, Figure 2), deployments PS124_8-1, PS124_16-8, PS124_78-8 and PS124_107-5. The eastern Filchner shelf differed greatly from the western shelf (Section 2.2.2), with no barnacle fragments evident and a much softer, heavily bioturbated seafloor common across much of the seafloor area surveyed. From side scan and forward-facing sonar data, occasional fish nest structures seemed to be present occasionally on the seafloor, though these were not clear from the camera data. Occasional drop stones or areas of grit visible at the ocean / seafloor interface (potentially associated with fish nest formation, Figure 6d) facilitated colonisation by a diverse sponge community (Figure 6a, 6c and 6d), despite the generally soft sediment composition of the seafloor. These sponges and larger drop stone features were commonly utilised by fish (Figure 6a and $\mathbf{6 d}$ ), crinoids (Figure $\mathbf{6 c}$ and $\mathbf{6 d}$ ) as points of increased elevation. Primary production detritus was observed entrapped within this seafloor structure and sponge spicules (Figure 6a 
https://doi.org/10.5194/essd-2021-444

Preprint. Discussion started: 28 February 2022

(c) Author(s) 2022. CC BY 4.0 License.

(c) (i)

and 6d), material likely providing nutrient input for the diverse range of further filter feeding fauna present across the region, including anemones (Figure 6d), soft corals (Figure 6c and 6d), bryozoans (Figure 6a), resembling the eastern shelf community (Pineda-Metz et al., 2019). Deposit feeding fauna typical for the Filchner trough community (Pineda-Metz et al., 2019), such as holothurians (Figure 6b) and scavengers such as starfish were also observed (Figure 6b). Dead icefish, often with a community of scavenging fauna, were observed at Station 16-8, the station in closest proximity to the active icefish breeding community observed in the northern Filchner Trough survey area (section 2.2.4, Figure 6b).

\subsubsection{Northern Filchner Trough}

Eight OFOBS deployments were made across the Northern Filchner Trough (NFT) (Table 1, Figure 2), deployments PS124_27-1, PS124_26-7, PS124_30-7, PS124_33-4. PS124_54-1, PS124_63-1, PS124_67-1 and PS124_101-1. This region was the most heavily surveyed during PS124, following the discovery of the icefish breeding colony, described Purser et al. (in press) (Figure 7a). This region covered both the trough floor, which was primarily associated with a sill structure marking the intersection of the Filchner Trough with the Weddell Sea, as well as the sloped flanks of the trough, running up to the western and eastern Filchner Shelf regions (see 2.2.2 and 2.2.3 above). Across the entire northern Filchner Trough survey area, which primarily covered the Filchner sill and the eastern flank of the northern section of the Filchner Trough, fish nest forms were abundantly clear in side scan and forward facing acoustic camera data (Figure 3). Nest forms across the active breeding colony area were immediately apparent within the still image data (Figure 7a), whereas elsewhere the forms were less distinct in the images, appearing older and degraded (Figure $\mathbf{7 b}$ and $\mathbf{7 c}$ ) or within much softer sediments and at a lower nest density (Figure 6d). Dead icefish carcasses were occasionally visible across the region, often undergoing active scavenging (Figure 7c and 7d). Aside from within the active breeding colony, no living icefish or fish eggs were observed across the area within

210 any of the nest forms, though bryozoans, soft corals, and sponges (Figure 7b) had colonised some of the seafloor depressions observed, resembling a mix between the eastern shelf and outer slope communities of the Filchner Region (Pineda-Metz et al., 2019).

\subsubsection{Central Filchner Trough}

215 One OFOBS deployment was made on the Central Filchner Trough (CFT) (Table 1, Figure 2), deployment PS124_72-8. Deployed at depths comparable with the active fish breeding colony observed with the northern Filchner Trough survey area (section 2.2.4) no active fish nests were observed in the area, though nest forms were occasionally observed (Figure 8d). In general, the sediments observed across this deployment were softer, with less detritus visible than further north. A megafauna community similar to the trough community was observed (Pineda-Metz et al., 2019), with occasional large octopi also observed, and further holothurian species (Figure 8a). 
https://doi.org/10.5194/essd-2021-444

Preprint. Discussion started: 28 February 2022

(c) Author(s) 2022. CC BY 4.0 License.

(c) (i)

\subsubsection{Southern Filchner Trough}

One OFOBS deployment was made on the Southern Filchner Trough (SFT) (Table 1, Figure 2), deployment PS124_94-5. Across this deployment, the Filchner Trough was observed to be generally far more abundant in rock and drop stone abundance

(Figure 9a, 9b and 9d), though this generally rocky area was occasionally crossed by areas of $100 \%$ soft sediment coverage. A differing faunal community was observed here than elsewhere in the Filchner Trough, with a lower population of hard substrates with filter feeding or encrusting fauna (Figure 9b) and high abundances of holothurians across the softer sediment areas (Figure 9c), typical for the Filchner Trough community (Pineda-Metz et al., 2019).

\subsubsection{Coastal Canyon}

One OFOBS deployment was made across a coastal canyon feature to the southern extent of the cruise survey area (CC) (Table 1, Figure 2), deployment PS124_90-13. The most southerly OFOBS deployment made during PS124 cut across an east-west trending canyon running from the Antarctic coast onto the shelf. Under an area occasionally free of sea ice, within the polynya formed as sea ice, and shelf ice fragments are carried in a westerly direction, the seafloor was abundant with life, and exhibited

235 a complex mix of topographies. Much of the seafloor was comprised of gravel, intermittent drop stones and intermixed softer sediments (Figure 10a). In areas with larger pebbles in evidence much of the seafloor was colonised by dense growths of soft corals, sponges and bryozoans (Figure 10b, 10d and upper left, 10c), resembling the southern shelf community (Pineda-Metz et al. 2019). Situated so close to the Antarctic coast and ice sheets, seafloor iceberg scouring was abundant across the station (Figure 10c), with contrasting degrees of seafloor recolonization evident (Gutt, 2001).

\section{Data availability}

All seafloor images collected with the OFOBS system are available from the data publisher PANGAEA. No preprocessing or processing stages were applied prior to upload, with no colour correction or light-vignetting algorithms applied. These images are provided with georeferenced positions for each image, as derived from the Posidonia system (https://doi.pangaea.de/10.1594/PANGAEA.936205 (Purser et al., 2021b) and

245 https://doi.pangaea.de/10.1594/PANGAEA.932827 (Purser et al., 2021c) as indicated on Table 1). Acoustic data for all deployments is also available from PANGAEA, with the raw side scan data available at: https://doi.pangaea.de/10.1594/PANGAEA.939322 (Hehemann et al., 2021b), forward facing acoustic camera data at: https://doi.pangaea.de/10.1594/PANGAEA.939341 (Purser et al., 2021a). Seafloor topographic maps derived from the side scan data are available at: https://doi.pangaea.de/10.1594/PANGAEA.939087 (Hehemann et al., 2021a).

250 The datasets are published under the Creative Commons Attribution 4.0 International (CC BY 4.0) license. Video data collected via the OFOBS system are available from the authors on request. 
https://doi.org/10.5194/essd-2021-444

Preprint. Discussion started: 28 February 2022

(c) Author(s) 2022. CC BY 4.0 License.

(c) (i)

\section{Author contributions}

AP ran the OFOBS throughout the expedition and planned seafloor deployments with MH, FW, LH, LB and EW, with the exception of deployment PS124_90-13, which was ran by LB. AP and LB ran and processed the OFOBS imaging systems.

$255 \mathrm{LH}, \mathrm{LB}$ and EW ran and processed the OFOBS acoustic systems. AN provided technical maintenance for OFOBS and deployed the device with the assistance of Polarstern crew on deck. LV insured appropriate cetacean watches were maintained throughout all deployments. SEAPM provided fauna support and placed the image data in context with previous cruises to the region, and current Weddell Sea seafloor habitat categorisation schemes. The benthic science planning for the cruise was coordinated by MH. FW was group leader for benthic imaging. AP wrote the manuscript, with input from SEAPM and additional contributions from all other co-authors.

\section{Competing interests}

The authors declare that they have no competing interests.

\section{Acknowledgements}

265 The captain, crew and scientific party of RV Polarstern expedition PS124 are thanked for their enthusiastic support and interest during this cruise, made during the second year of the global COVID-19 pandemic. The complexities of conducting research in Antarctica during epidemic were smoothed by the AWI logistics and ship co-ordinations teams. Steffen Hain is thanked for assisting in insuring we fulfilled our environmental commitments and commitment to the Antarctic Treaty during the expedition. Ulrich Hoge is thanked for onshore support of the OFOBS system. Stefanie Schumacher and Janine Felden from the PANGAEA team are thanked for their helpful and efficient work in uploading this data to archive. The following AWI grant numbers are acknowledged for supporting the work incorporated into this data set: AWI_PS124_02, AWI_PS124_03, AWI_PS124_05 and AWI_PS124_06.

\section{References}

Arndt, J. E., Schenke, H. W., Jakobsson, M., Nitsche, F. O., Buys, G., Goleby, B., Rebesco, M., Bohoyo, F., Hong, J., Black, 275 J., Greku, R., Udintsev, G., Barrios, F., Reynoso-Peralta, W., Taisei, M., and Wigley, R.: The International Bathymetric Chart of the Southern Ocean (IBCSO) Version 1.0-A new bathymetric compilation covering circum-Antarctic waters, 40, 3111-3117, https://doi.org/10.1002/grl.50413, 2013.

Boetius, A. and Purser, A.: The Expedition PS101 of the Research Vessel POLARSTERN to the Arctic Ocean in 2016, Alfred-Wegener-Institut, Helmholtz-Zentrum für Polar- und Meeresforschung, Bremerhaven, Germany, 230 pp., https://doi.org/10.2312/BzPM_0706_2017, 2017.

Gerdes, D.: Antarctic trials of the multi-box corer, a new device for benthos sampling, 26, 35-38, https://doi.org/10.1017/S0032247400022749, 1990. 
https://doi.org/10.5194/essd-2021-444

Preprint. Discussion started: 28 February 2022

(c) Author(s) 2022. CC BY 4.0 License.

Gutt, J.: On the direct impact of ice on marine benthic communities, a review, Polar Biol, 24, 553-564, https://doi.org/10.1007/s003000100262, 2001.

285 Hattermann, T., Nicholls, K. W., Hellmer, H. H., Davis, P. E. D., Janout, M. A., Østerhus, S., Schlosser, E., Rohardt, G., and Kanzow, T.: Observed interannual changes beneath Filchner-Ronne Ice Shelf linked to large-scale atmospheric circulation, Nat Commun, 12, 2961, https://doi.org/10.1038/s41467-021-23131-x, 2021.

Hehemann, L., Boehringer, L., Purser, A., Werner, E., and Wenzhöfer, F.: Seafloor bathymetric maps derived from side scan data collected along OFOBS profiles during POLARSTERN cruise PS124 to the southern Weddell Sea, [data set],

290 https://doi.pangaea.de/10.1594/PANGAEA.939087, 2021a.

Hehemann, L., Purser, A., Boehringer, L., Werner, E., and Wenzhöfer, F.: Side scan sonar and swath bathymetry collected along OFOBS profiles during POLARSTERN cruise PS124, [data set], https://doi.pangaea.de/10.1594/PANGAEA.939322, $2021 b$.

Hellmer, H. H. and Holtappels, M.: The Expedition PS124 of the Research Vessel POLARSTERN to the southern Weddell

295 Sea in 2021, Alfred Wegener Institute for Polar and Marine Research, Bremerhaven, 237 pp., https://doi.org/10.48433/BzPM_0755_2021, 2021.

Jaffe, J.: Underwater Optical Imaging: The Past, the Present, and the Prospects, Oceanic Engineering, IEEE Journal of, 40, 683-700, https://doi.org/10.1109/JOE.2014.2350751, 2015.

Janout, M. A., Hellmer, H. H., Hattermann, T., Huhn, O., Sültenfuss, J., Østerhus, S., Stulic, L., Ryan, S., Schröder, M., and

300 Kanzow, T.: FRIS Revisited in 2018: On the Circulation and Water Masses at the Filchner and Ronne Ice Shelves in the Southern Weddell Sea, 126, e2021JC017269, https://doi.org/10.1029/2021JC017269, 2021.

Jansen, J., Hill, N. A., Dunstan, P. K., McKinlay, J., Sumner, M. D., Post, A. L., Eleaume, M. P., Armand, L. K., Warnock, J. P., Galton-Fenzi, B. K., and Johnson, C. R.: Abundance and richness of key Antarctic seafloor fauna correlates with modelled food availability, Nat. Ecol. Evol., 2, 71-80, https://doi.org/10.1038/s41559-017-0392-3, 2018.

305 Knust, R.: Polar Research and Supply Vessel POLARSTERN Operated by the Alfred-Wegener-Institute, 3, 119, https://doi.org/10.17815/jlsrf-3-163, 2017.

Marsh, L., Huvenne, V. A. I., and Jones, D. O. B.: Geomorphological evidence of large vertebrates interacting with the seafloor at abyssal depths in a region designated for deep-sea mining, R. Soc. Open Sci., 5, 180286, https://doi.org/10.1098/rsos.180286, 2018.

310 Morganti, T. M., Purser, A., Rapp, H. T., German, C. R., Jakuba, M. V., Hehemann, L., Blendl, J., Slaby, B. M., and Boetius, A.: In situ observation of sponge trails suggests common sponge locomotion in the deep central Arctic, Current Biology, 31, R368-R370, https://doi.org/10.1016/j.cub.2021.03.014, 2021.

Piepenburg, D., Buschmann, A., Driemel, A., Grobe, H., Gutt, J., Schumacher, S., Segelken-Voigt, A., and Sieger, R.: Seabed images from Southern Ocean shelf regions off the northern Antarctic Peninsula and in the southeastern Weddell Sea, 315 9, 461-469, https://doi.org/10.5194/essd-9-461-2017, 2017.

Pineda-Metz, S. E. A. and Gerdes, D.: Seabed images versus corer sampling: a comparison of two quantitative approaches for the analysis of marine benthic communities in the southern Weddell Sea (Southern Ocean), Polar Biol, 41, 515-526, https://doi.org/10.1007/s00300-017-2211-3, 2018. 
https://doi.org/10.5194/essd-2021-444

Preprint. Discussion started: 28 February 2022

(c) Author(s) 2022. CC BY 4.0 License.

(c) (1)

Pineda-Metz, S. E. A., Isla, E., and Gerdes, D.: Benthic communities of the Filchner Region (Weddell Sea, Antarctica), 628, 37-54, https://doi.org/10.3354/meps13093, 2019.

Purser, A., Herr, H., Dreutter, S., Dorschel, B., Glud, R. N., Hehemann, L., Hoge, U., Jamieson, A. J., Linley, T. D., Stewart, H. A., and Wenzhoefer, F.: Depression chains in seafloor of contrasting morphology, Atacama Trench margin: a comment on Marsh et al. (2018), R. Soc. Open Sci., 6, 182053, https://doi.org/10.1098/rsos.182053, 2019a.

Purser, A., Marcon, Y., Dreutter, S., Hoge, U., Sablotny, B., Hehemann, L., Lemburg, J., Dorschel, B., Biebow, H., and 325 Boetius, A.: Ocean Floor Observation and Bathymetry System (OFOBS): A New Towed Camera/Sonar System for DeepSea Habitat Surveys, 44, 87-99, https://doi.org/10.1109/JOE.2018.2794095, 2019 b.

Purser, A., Hehemann, L., Boehringer, L., Werner, E., and Wenzhöfer, F.: Forward facing acoustic camera seafloor sonar data from the southern Weddell Sea, collected during POLARSTERN cruise PS124, [data set], https://doi.pangaea.de/10.1594/PANGAEA.939341,2021a.

330 Purser, A., Boehringer, L., Hehemann, L., and Wenzhöfer, F.: Ocean Floor Observation and Bathymetry System (OFOBS) images of Neopagetopsis ionah ice fish nest arrays in the Filchner Trough, Antarctica collected during the PS124 Polarstern expedition, [data set], https://doi.pangaea.de/10.1594/PANGAEA.936205, $2021 \mathrm{~b}$.

Purser, A., Hehemann, L., Boehringer, L., Werner, E., and Wenzhöfer, F.: Ocean Floor Observation and Bathymetry System (OFOBS) seafloor images of the Weddell Sea, Antarctica collected during the PS124 Polarstern expedition, [data set],

335 https://doi.pangaea.de/10.1594/PANGAEA.932827, 2021c.

Purser, A., Dreutter, S., Griffiths, H., Hehemann, L., Jerosch, K., Nordhausen, A., Piepenburg, D., Richter, C., Schröder, H., and Dorschel, B.: Seabed video and still images from the northern Weddell Sea and the western flanks of the Powell Basin, 13, 609-615, https://doi.org/10.5194/essd-13-609-2021, 2021d.

Schoening, T., Purser, A., Langenkämper, D., Suck, I., Taylor, J., Cuvelier, D., Lins, L., Simon-Lledó, E., Marcon, Y., 340 Jones, D. O. B., Nattkemper, T., Köser, K., Zurowietz, M., Greinert, J., and Gomes-Pereira, J.: Megafauna community assessment of polymetallic-nodule fields with cameras: platform and methodology comparison, 17, 3115-3133, https://doi.org/10.5194/bg-17-3115-2020, 2020.

Wolff, L. M. and Badri-Hoeher, S.: Imaging sonar-based fish detection in shallow waters, in: 2014 Oceans - St. John's, 2014 Oceans - St. John's, 1-6, https://doi.org/10.1109/OCEANS.2014.7003213, 2014.

\section{Figures}




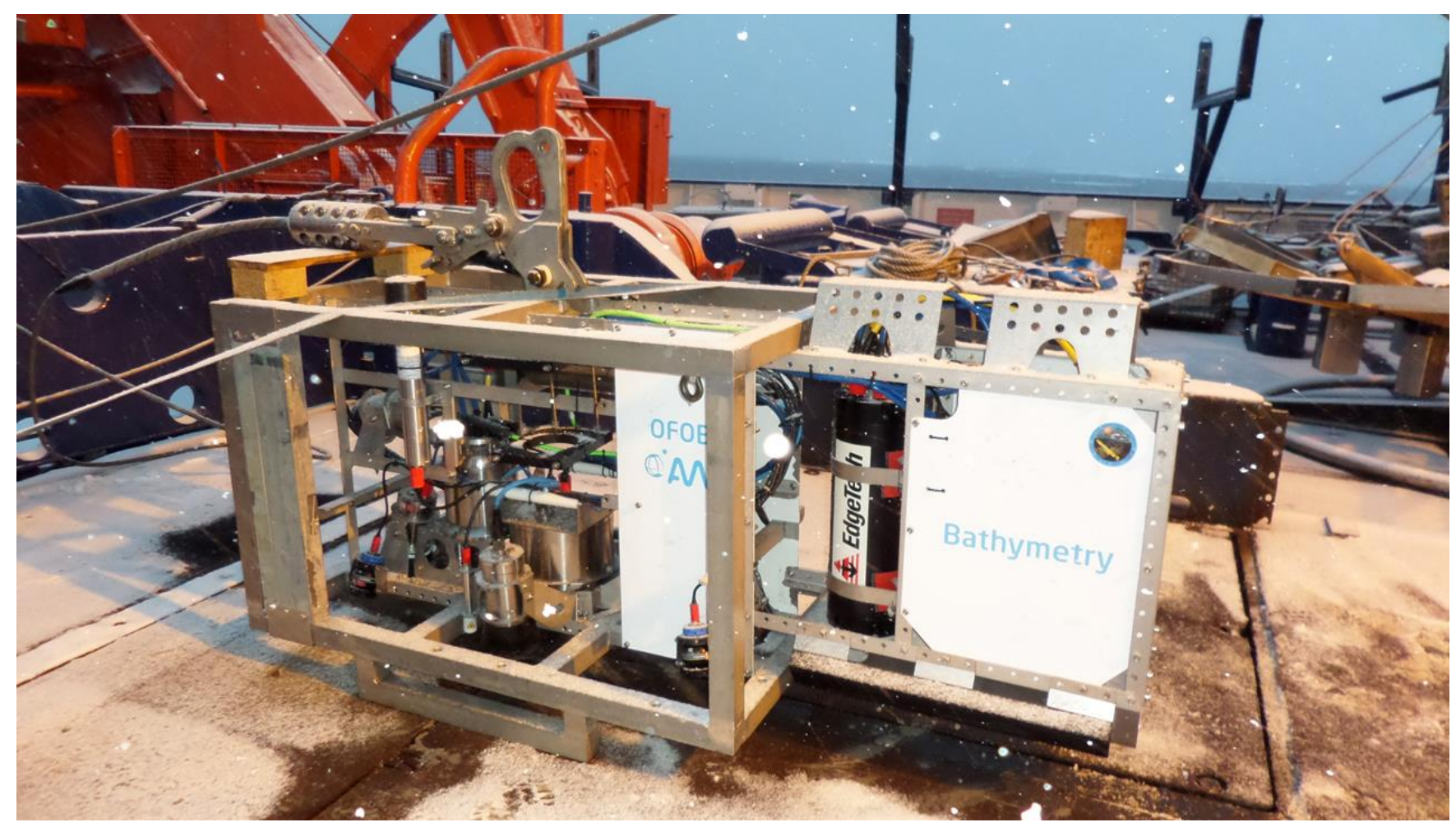

Figure 1: The Ocean Floor Observation and Bathymetry System (OFOBS) of the Alfred Wegener Institute (AWI),

Helmholtz Centre for Polar and Marine Research, on deck awaiting deployment during the PS124 expedition to the southern Weddell Sea (February-March 2021). 


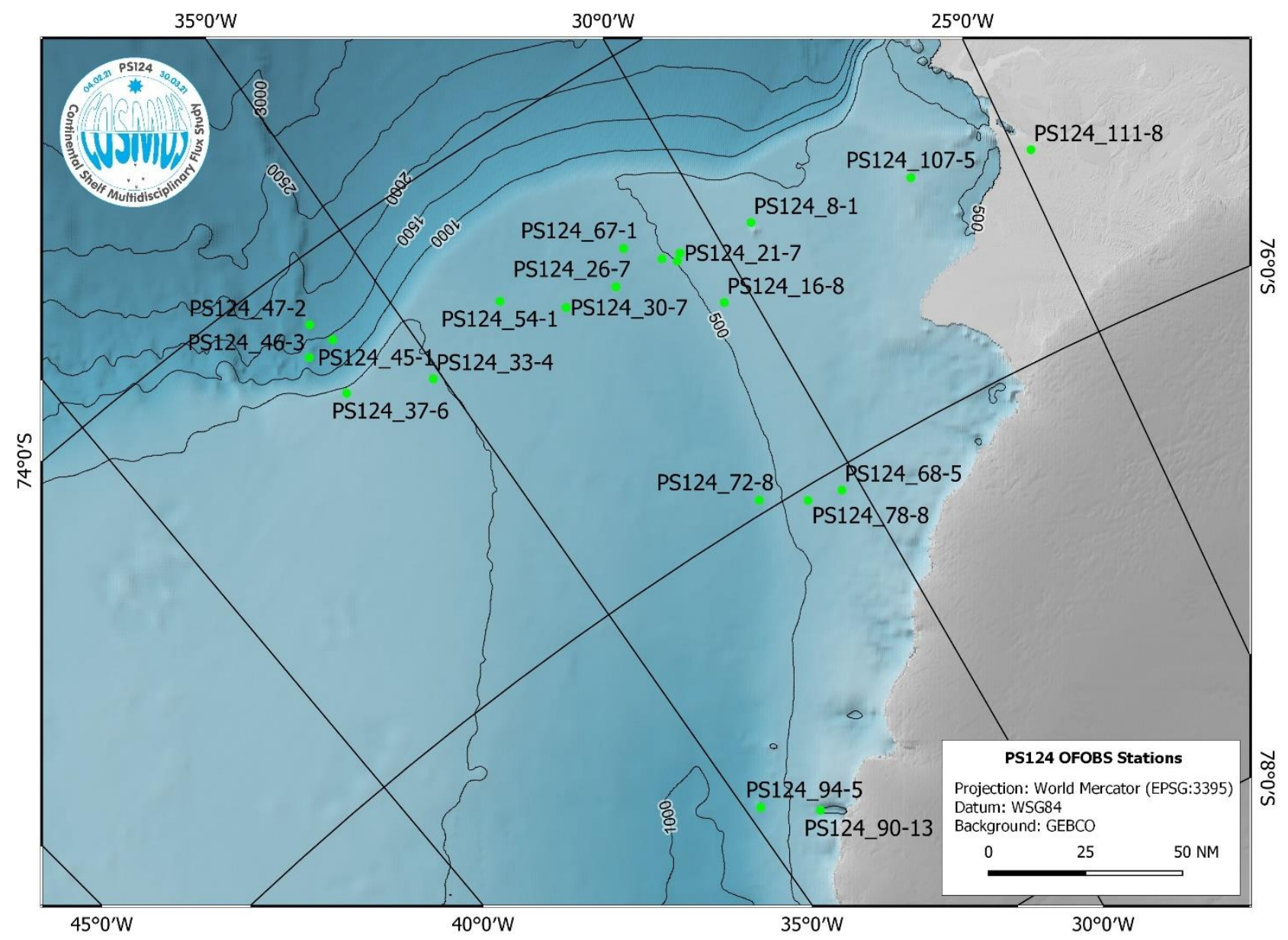

Figure 2: Regional map showing the positions of OFOBS deployments made during RV Polarstern cruise PS124. 
Preprint. Discussion started: 28 February 2022

(C) Author(s) 2022. CC BY 4.0 License.

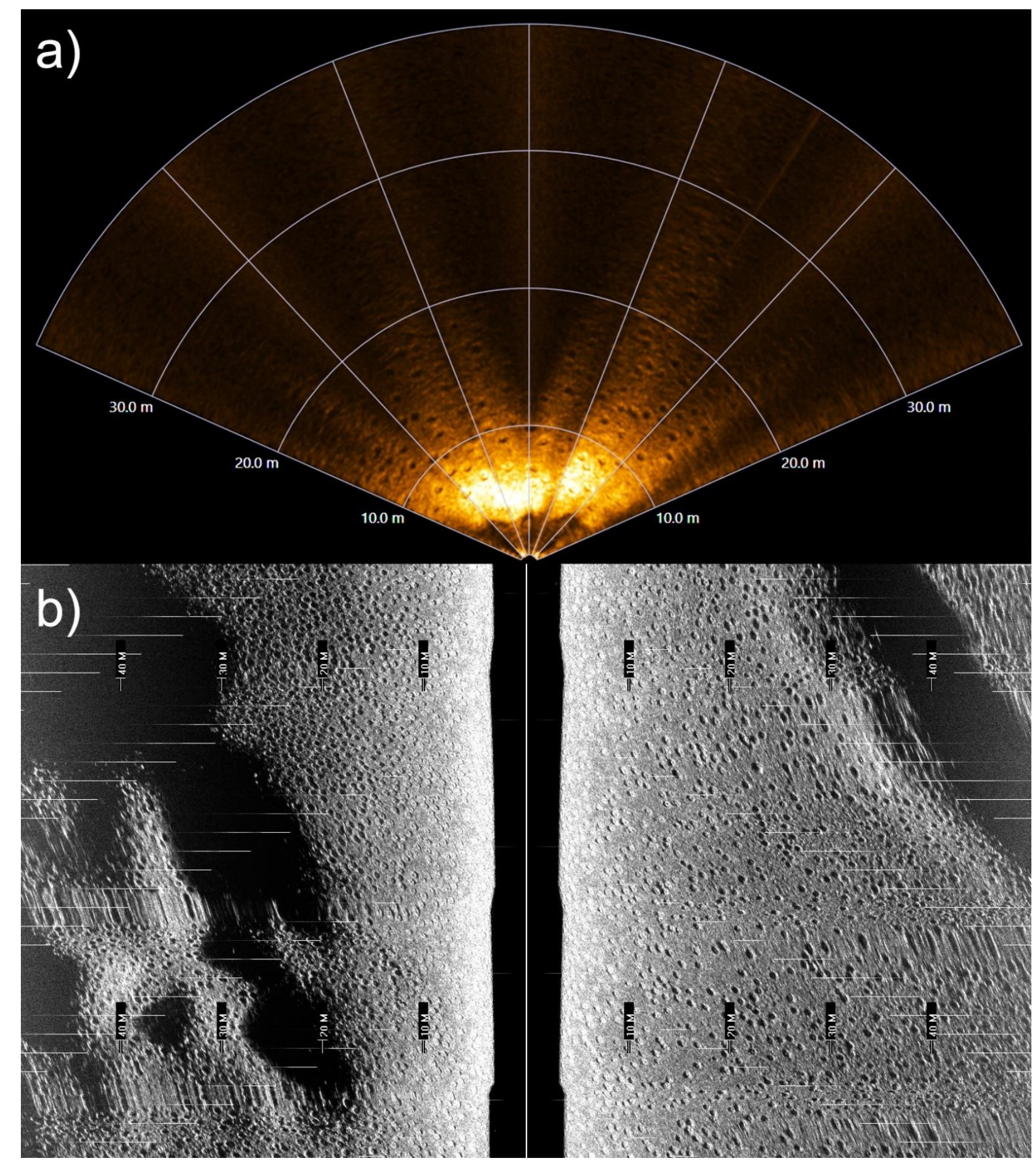


Figure 3: Raw acoustic data collected via the OFOBS during deployment PS124_63-1. Data shows an area of seafloor wholly covered by an array of actively nesting ice fish. a) Forward facing acoustic camera. b) High frequency side scan sonar data. An area of slightly undulating seafloor is wholly covered with actively nesting ice fish. The white, bright reflectors within the centre of many of the ice fish nests indicates the presence of a brooding fish.

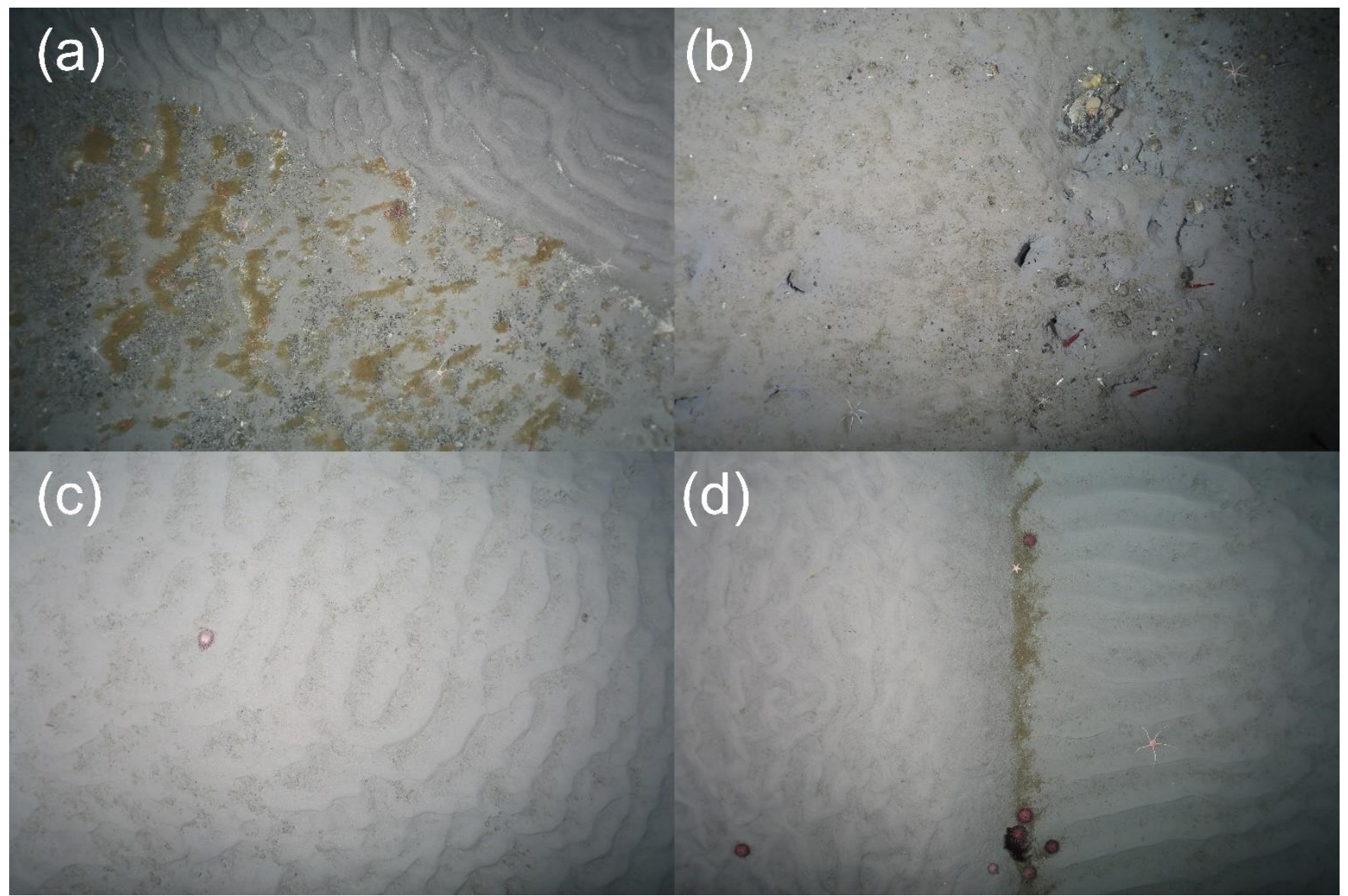

365 Figure 4: Typical seafloor images collected from each of the OFOBS surveys made of the Weddell Sea Shelf seafloor during RV Polarstern cruise 124. (a) Station PS124_45-1, SW-RELEASER_2021_02_22 at 04_19_03 IMG_0199.JPG, (b) Station PS124_46-3. HOTKEY_2021_02_22 at 19_24_57 IMG_0056.JPG, (c) Station PS124_47-2, TIMER_2021_02_23 at 03_15_59 IMG_0405.JPG, (d) Station PS124_47-2, TIMER_2021_02_23 at 03_14_37 IMG_0400-JPG. The three red points within each image represent the sizing lasers $(50 \mathrm{~cm}$ spacing). All images are presented here and in the dataset with no manipulation or colour correction. 


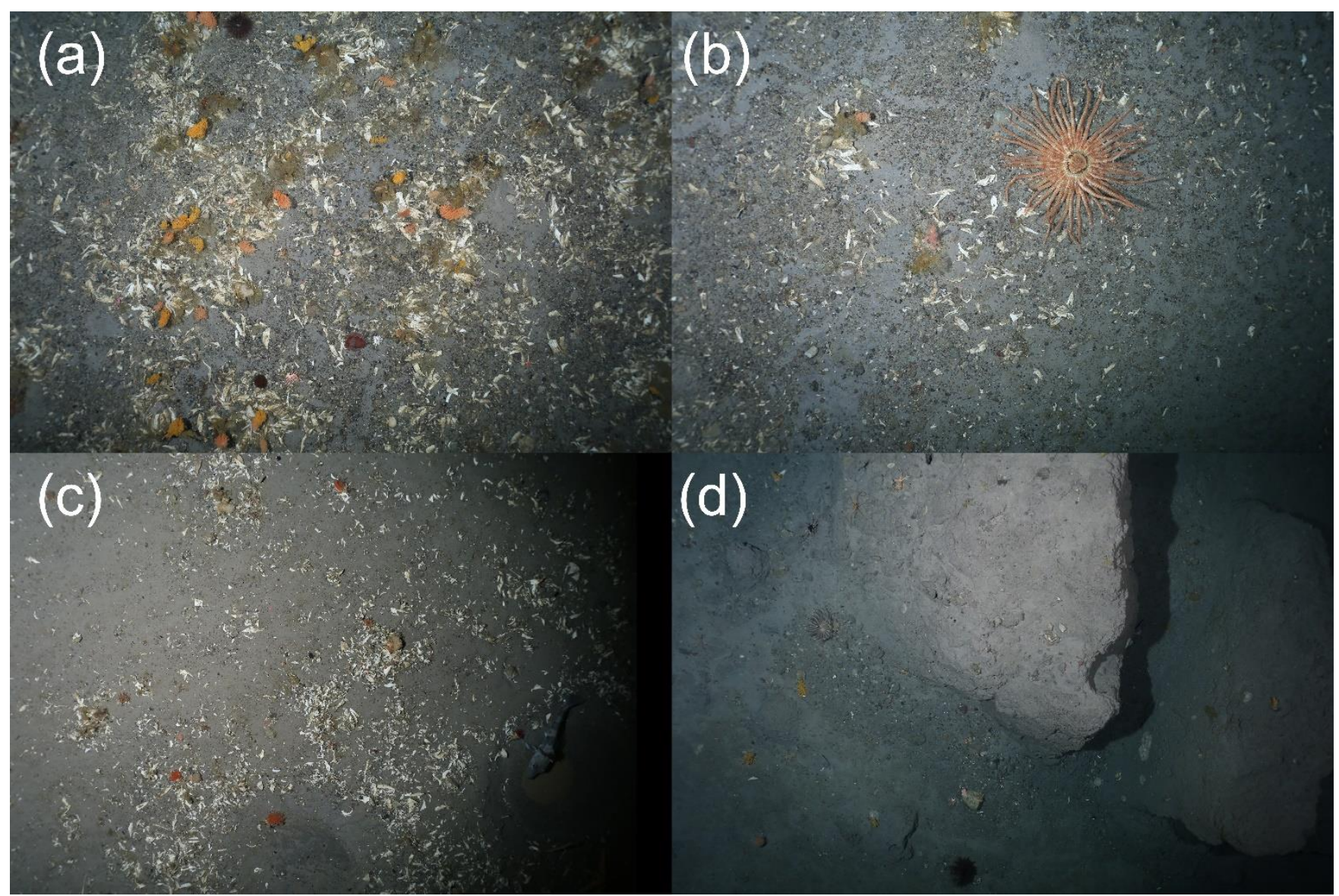

Figure 5: Typical seafloor images collected from each of the OFOBS surveys made of the Western Filchner Shelf seafloor during RV Polarstern cruise 124. All images were taken during deployment PS124_37-6. (a) SW_RELEASER_2021_02_21 at 01_36_51 IMG_0127.JPG，(b) SW_RELEASER_2021_02_21 at 01_37_28 IMG_0130-JPG, (c) SW_RELEASER_2021_02_21 at 02_44_44 IMG_0336.JPG, (d) SW_RELEASER_2021_02_21 at 03_56_56 IMG_0579.JPG. The three red points within each image represent the sizing lasers (50 cm spacing). All images are presented here and in the dataset with no manipulation or colour correction. 


\section{(a)}

\section{(b)}

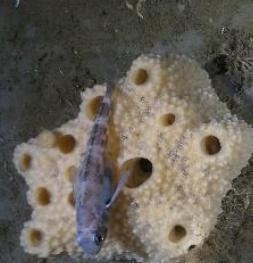

(c)

Figure 6: Typical seafloor images collected from each of the OFOBS surveys made of the Eastern Filchner Shelf seafloor during RV Polarstern cruise 124. (a) Station PS124_8_1, HOTKEY_2021_02_12 at 04_27_23 IMG_0081.JPG, (b) Station PS124_16-08, HOTKEY_2021_02_15 at 01_40_22 IMG_0567.JPG, (c) Station PS124_68-5, TIMER_2021_03_01 at 02_19_28.IMG, (d) Station PS124_107-05, TIMER_2021_03_12 at 02_17_42 IMG_0032.JG.

385 The three red points within each image represent the sizing lasers $(50 \mathrm{~cm}$ spacing). All images are presented here and in the dataset with no manipulation or colour correction. 


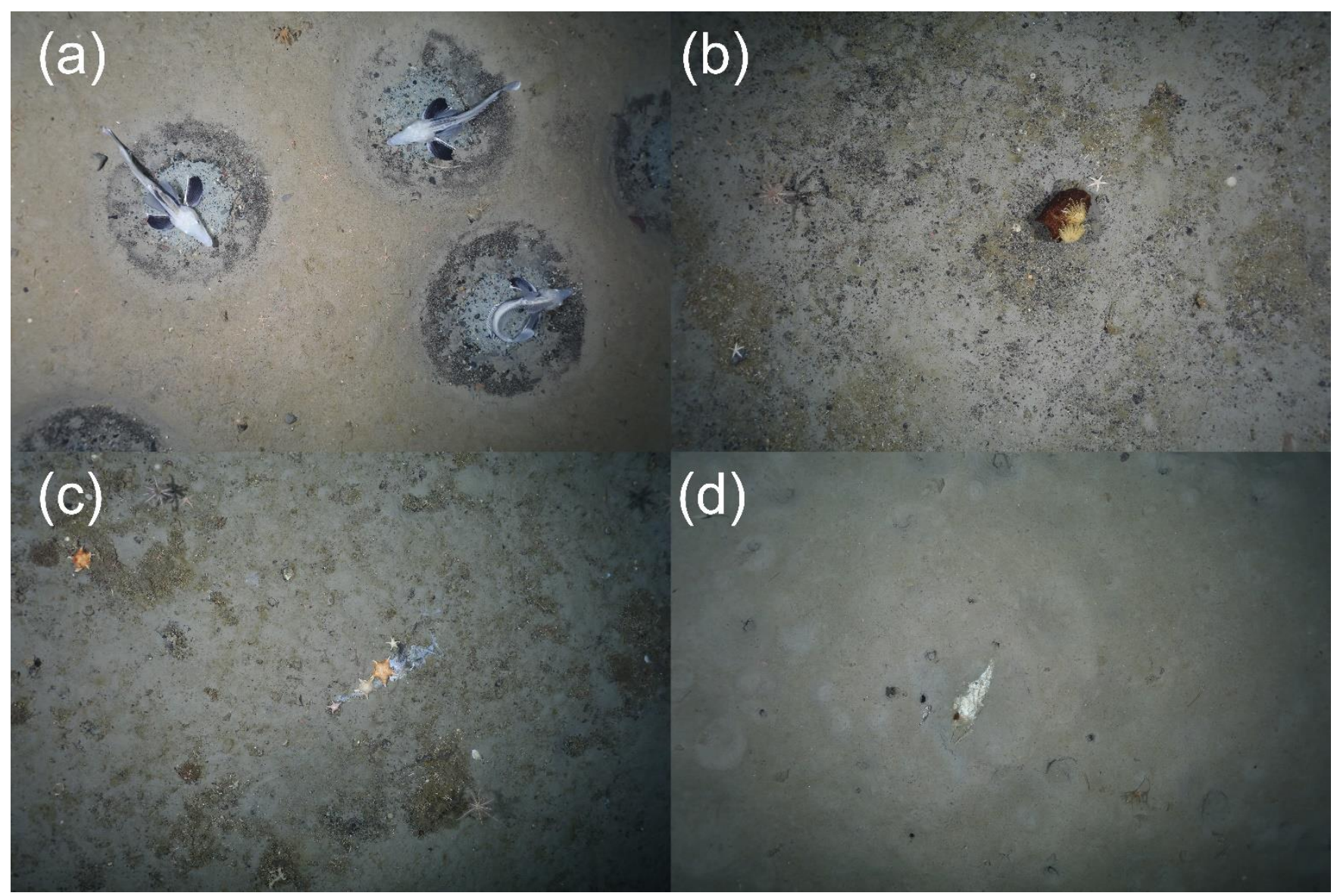

Figure 7: Typical seafloor images collected from each of the OFOBS surveys made of the Northern Filchner Trough seafloor during RV Polarstern cruise 124. Station PS124_21-7, HOTKEY_2021_02_16 at 04_05_34 IMG_0112.JPG, (b) Station PS124_26-07, TIMER_2021_02_17 at 00_43_30 IMG_0124.JPG, (c) Station 30-07, SW_RELEASER_2021_02_18 at 03_26_43 IMG_0667.JPG, (d) Station PS124_33-04, SW_RELEASER_2021_02_19 at 03_55_18 IMG_0162.JPG. The three red points within each image represent the sizing lasers (50 cm spacing). All images are presented here and in the dataset with no manipulation or colour correction. 


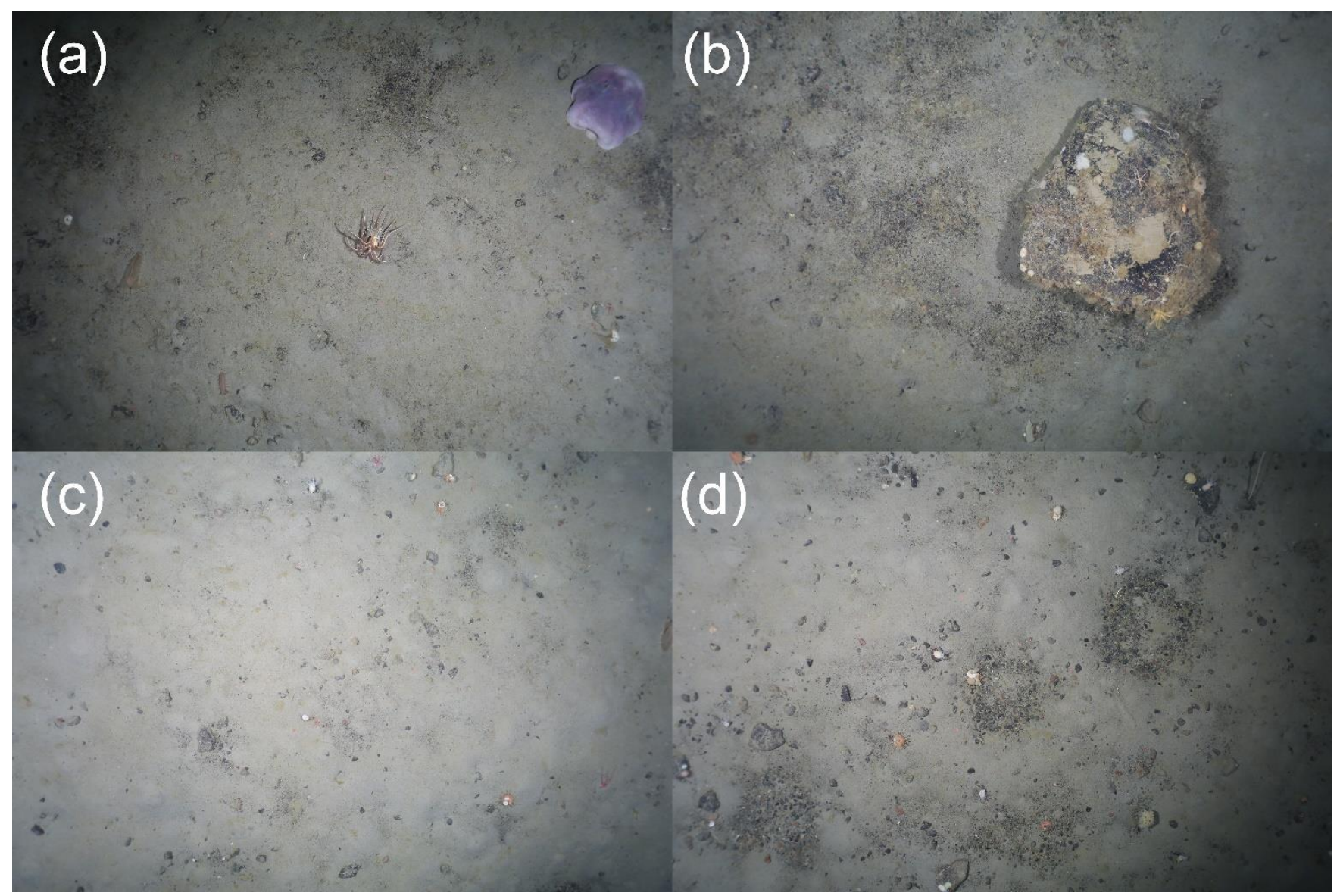

Figure 8: Typical seafloor images collected from each of the OFOBS surveys made of the Central Filchner Trough seafloor during RV Polarstern cruise 124. All images were taken during Station PS124_72-08. (a) SW_RELEASER_2021_03_02 at 00_48_38 IMG_0091.JPG，(b) SW_RELEASER_2021_03_02 at 01_08_57 IMG_0159.JPG, (c) TIMER_2021_03_02 at 03_44_06 IMG_0650.JPG, (d) SW_RELEASER_2021_03_02 at 04_08_38 IMG_0726-IMG. The three red points within each image represent the sizing lasers $(50 \mathrm{~cm}$ spacing). All images are presented here and in the dataset with no manipulation or colour correction. 


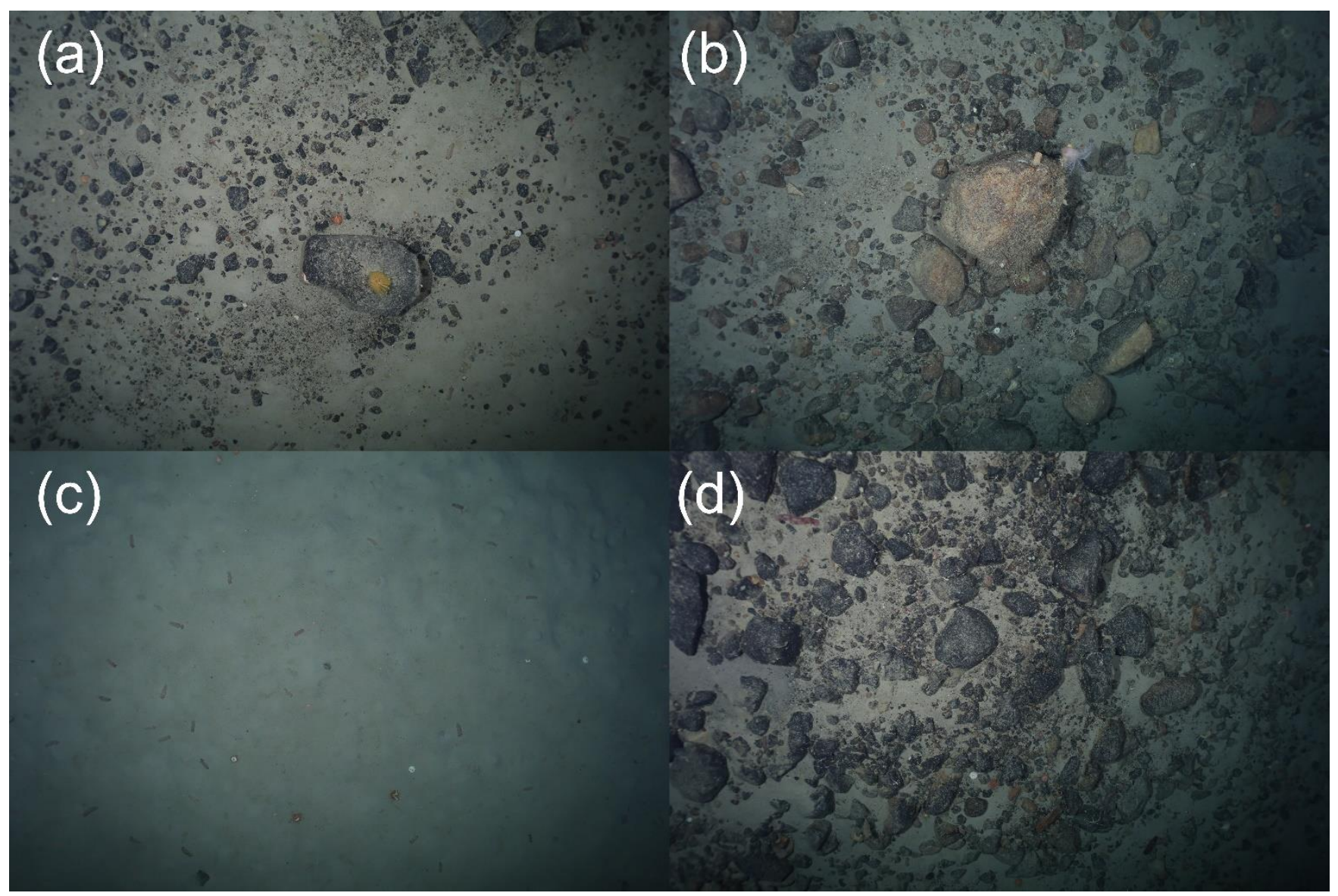

405 Figure 9: Typical seafloor images collected from each of the OFOBS surveys made of the Southern Filchner Trough seafloor during RV Polarstern cruise 124. All images were taken during deployment Station PS124_94-5. (a) SW_RELEASER_2021_03_07 at 23_03_46 IMG_0115.JPG, (b) SW_RELEASER_2021_03_08 at 00_31_37-JPG, (c) TIMER_2021_03_07 at 23_29_54 IMG_0207.JPG, (d) TIMER_2021_03_07 at 23_30_14 IMG_0209-JPG. The three red points within each image represent the sizing lasers $(50 \mathrm{~cm}$ spacing). All images are presented here and in the 410 dataset with no manipulation or colour correction. 


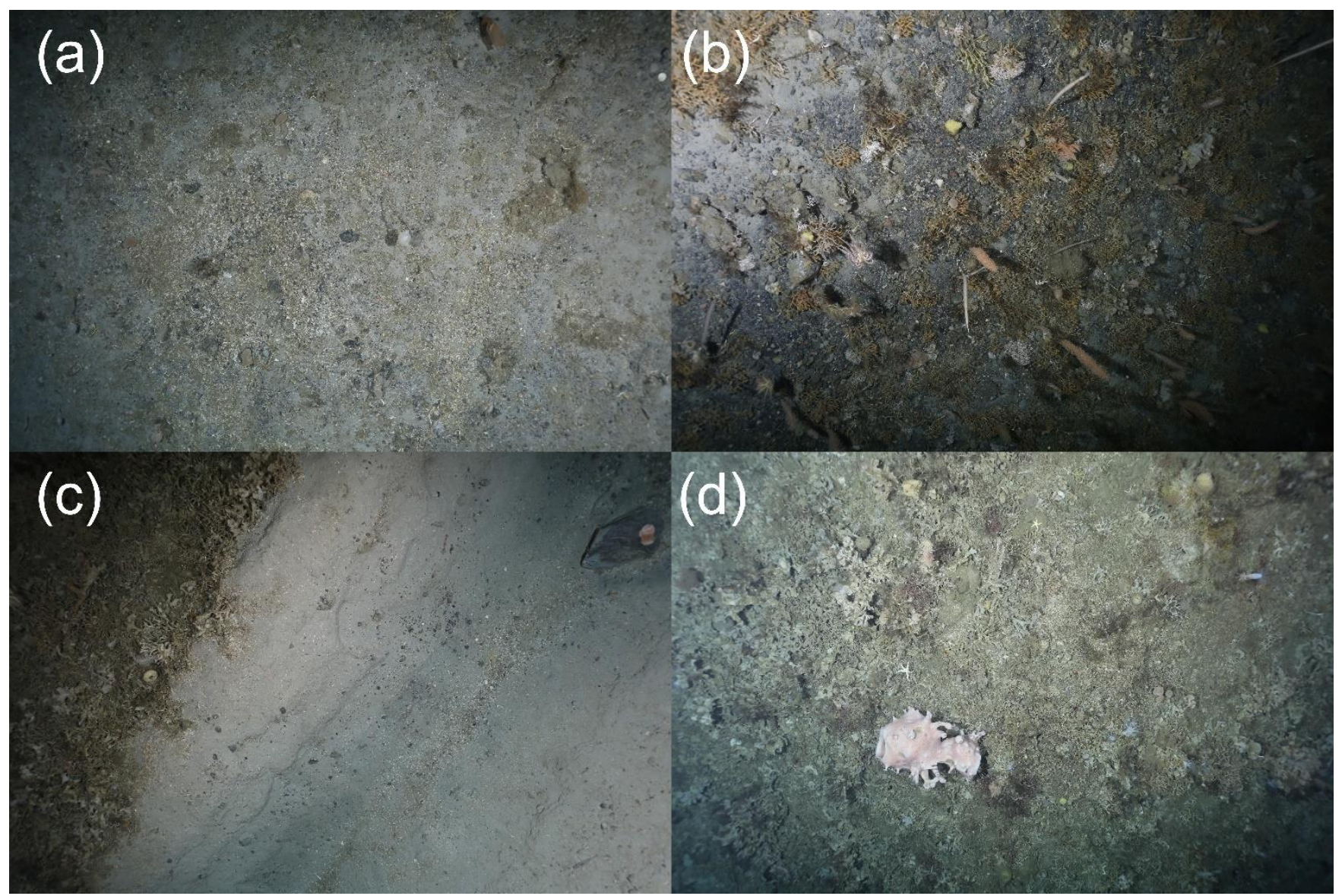

Figure 10: Typical seafloor images collected from each of the OFOBS surveys made of the Coastal Canyon seafloor

415 during RV Polarstern cruise 124. All images were taken during deployment Station 90-13. a) TIMER_2021_03_07 at 01_48_12 IMG_0078.JPG b) TIME_2021_03_07 at 02_48_47 IMG_0305.JPG c) SW_RELEASER_2021_03_07 at 03_31_08 IMG_0453.JPG d) SW_RELEASER_2021_03_07 at 04_50_44 IMG_0716.JPG. The three red points within each image represent the sizing lasers $(50 \mathrm{~cm}$ spacing). All images are presented here and in the dataset with no manipulation or colour correction. 
https://doi.org/10.5194/essd-2021-444

Preprint. Discussion started: 28 February 2022

(c) Author(s) 2022. CC BY 4.0 License.

Table 1: Locations of OFOBS deployments made during PS124. Start and end position coordinates and times are given,

430 in addition to the number of images collected during each deployment. Images from image dataset 'Fishnests' are available at: https://doi.pangaea.de/10.1594/PANGAEA.932827, with images from the 'Weddell Sea' dataset available at: https://doi.pangaea.de/10.1594/PANGAEA.936205

\begin{tabular}{|c|c|c|c|c|c|c|c|c|c|c|c|}
\hline Station & Region & $\begin{array}{l}\text { Date } \\
\text { (DD.MM.YYYY) }\end{array}$ & $\begin{array}{l}\text { Start } \\
\text { (UTC) } \\
\end{array}$ & $\begin{array}{l}\text { End } \\
\text { (UTC) }\end{array}$ & $\begin{array}{l}\text { Latitude } \\
\text { start }\end{array}$ & $\begin{array}{l}\text { Longitude } \\
\text { start }\end{array}$ & $\begin{array}{l}\text { Latitude } \\
\text { end }\end{array}$ & $\begin{array}{l}\text { Longitude } \\
\text { end }\end{array}$ & $\begin{array}{l}\text { Depth } \\
\text { (m) }\end{array}$ & $\begin{array}{l}\text { No. of } \\
\text { images }\end{array}$ & Image dataset \\
\hline PS124_8-1 & EFS & 12.02 .2021 & $03: 52$ & $06: 11$ & $74^{\circ} 54.401^{\prime} \mathrm{S}$ & $029^{\circ} 24.611^{\prime} \mathrm{W}$ & $74^{\circ} 55.358^{\prime} \mathrm{S}$ & $029^{\circ} 25.456^{\prime} \mathrm{W}$ & $406-408$ & 531 & Weddell Sea \\
\hline PS124_16-8 & EFS & 14.02 .2021 & $23: 25$ & $03: 36$ & $75^{\circ} 08.927^{\prime} \mathrm{S}$ & $030^{\circ} 25.653^{\prime} \mathrm{W}$ & $75^{\circ} 08.572^{\prime} \mathrm{S}$ & $030^{\circ} 16.442^{\prime} \mathrm{W}$ & $452-538$ & 1017 & Weddell Sea \\
\hline PS124_21-7 & NFT & 16.02 .2021 & $03: 48$ & $06: 32$ & $74^{\circ} 52.115^{\prime} \mathrm{S}$ & $030^{\circ} 39.731^{\prime} \mathrm{W}$ & $74^{\circ} 52.162^{\prime} \mathrm{S}$ & $030^{\circ} 35.891^{\prime} \mathrm{W}$ & $494-486$ & 1192 & Fishnests \\
\hline PS124_26-7 & NFT & 17.02 .2021 & $00: 22$ & $03: 32$ & $74^{\circ} 50.881^{\prime} \mathrm{S}$ & $031^{\circ} 51.034^{\prime} \mathrm{W}$ & $74^{\circ} 50.930^{\prime} \mathrm{S}$ & $031^{\circ} 56.031^{\prime} \mathrm{W}$ & $638-634$ & 730 & Weddell Sea \\
\hline PS124_30-7 & NFT & 18.02 .2021 & $00: 24$ & $05: 18$ & $74^{\circ} 48.657^{\prime} \mathrm{S}$ & $032^{\circ} 42.403^{\prime} \mathrm{W}$ & $74^{\circ} 46.991^{\prime} \mathrm{S}$ & $032^{\circ} 34.278^{\prime} \mathrm{W}$ & $600-593$ & 1026 & Weddell Sea \\
\hline PS124_33-4 & NFT & 19.02 .2021 & $03: 13$ & $05: 16$ & $74^{\circ} 43.237^{\prime} \mathrm{S}$ & $035^{\circ} 11.913^{\prime} \mathrm{W}$ & $74^{\circ} 43.166^{\prime} \mathrm{S}$ & $035^{\circ} 07.791^{\prime} \mathrm{W}$ & $497-501$ & 459 & Weddell Sea \\
\hline PS124_37-6 & WFS & 21.02 .2021 & 01:09 & 05:01 & $74^{\circ} 34.572^{\prime} \mathrm{S}$ & $036^{\circ} 24.472^{\prime} \mathrm{W}$ & $74^{\circ} 36.609^{\prime} \mathrm{S}$ & $036^{\circ} 25.492^{\prime} \mathrm{W}$ & $424-408$ & 800 & Weddell Sea \\
\hline PS124_45-1 & WSS & 22.02 .2021 & $03: 48$ & $04: 55$ & $74^{\circ} 21.739^{\prime} \mathrm{S}$ & $036^{\circ} 05.019^{\prime} \mathrm{W}$ & $74^{\circ} 21.813^{\prime} \mathrm{S}$ & $036^{\circ} 02.754^{\prime} \mathrm{W}$ & $1467-1457$ & 350 & Weddell Sea \\
\hline PS124_46-3 & WSS & 22.02 .2021 & $19: 10$ & $20: 47$ & $74^{\circ} 21.864^{\prime} \mathrm{S}$ & $036^{\circ} 32.827^{\prime} \mathrm{W}$ & $74^{\circ} 22.543^{\prime} \mathrm{S}$ & $036^{\circ} 30.397^{\prime} \mathrm{W}$ & $1200-1188$ & 449 & Weddell Sea \\
\hline PS124_47-2 & WSS & 23.02 .2021 & $01: 51$ & $05: 29$ & $74^{\circ} 15.255^{\prime} \mathrm{S}$ & $036^{\circ} 14.067^{\prime} \mathrm{W}$ & $74^{\circ} 15.285^{\prime} \mathrm{S}$ & $036^{\circ} 06.166^{\prime} \mathrm{W}$ & $1726-1785$ & 953 & Weddell Sea \\
\hline PS124_54-1 & NFT & 25.02 .2021 & $02: 43$ & 05:09 & $74^{\circ} 38.099^{\prime} \mathrm{S}$ & $033^{\circ} 32.621^{\prime} \mathrm{W}$ & $74^{\circ} 39.481^{\prime} \mathrm{S}$ & $033^{\circ} 33.167^{\prime} \mathrm{W}$ & $608-593$ & 675 & Weddell Sea \\
\hline PS124_63-1 & NFT & 27.02 .2021 & $00: 51$ & $06: 00$ & $74^{\circ} 50.909^{\prime} \mathrm{S}$ & $030^{\circ} 56.969^{\prime} \mathrm{W}$ & $74^{\circ} 53.412^{\prime} \mathrm{S}$ & $030^{\circ} 30.966^{\prime} \mathrm{W}$ & $534-477$ & 2186 & Fishnest \\
\hline PS124_67-1 & NFT & 27.02 .2021 & $18: 00$ & $06: 16$ & $74^{\circ} 43.837^{\prime} \mathrm{S}$ & $031^{\circ} 24.087^{\prime} \mathrm{W}$ & $74^{\circ} 51.513^{\prime} \mathrm{S}$ & $030^{\circ} 26.118^{\prime} \mathrm{W}$ & $588-468$ & 4554 & Fishnest \\
\hline PS124_68-5 & EFS & 01.03 .2021 & $01: 36$ & $03: 15$ & $76^{\circ} 05.405^{\prime} \mathrm{S}$ & $030^{\circ} 20.071^{\prime} \mathrm{W}$ & $76^{\circ} 06.065^{\prime} \mathrm{S}$ & $030^{\circ} 17.602^{\prime} \mathrm{W}$ & $476-470$ & 357 & Weddell Sea \\
\hline PS124_72-8 & CFT & 02.03 .2021 & $00: 35$ & $06: 16$ & $75^{\circ} 56.519^{\prime} \mathrm{S}$ & $031^{\circ} 40.739^{\prime} \mathrm{W}$ & $75^{\circ} 55.917^{\prime} \mathrm{S}$ & $031^{\circ} 26.418^{\prime} \mathrm{W}$ & $689-598$ & 1097 & Weddell Sea \\
\hline PS124_78-8 & EFS & 04.03 .2021 & $00: 56$ & $06: 18$ & $76^{\circ} 03.472^{\prime} \mathrm{S}$ & $030^{\circ} 56.521^{\prime} \mathrm{W}$ & $76^{\circ} 04.122^{\prime} \mathrm{S}$ & $030^{\circ} 40.934^{\prime} \mathrm{W}$ & $466-461$ & 1109 & Weddell Sea \\
\hline PS124_90-10 & $\mathrm{CC}$ & 07.03 .2021 & 01:39 & $06: 57$ & $77^{\circ} 12.154^{\prime} \mathrm{S}$ & $033^{\circ} 48.548^{\prime} \mathrm{W}$ & $77^{\circ} 10.446^{\prime} \mathrm{S}$ & $033^{\circ} 37.326^{\prime} \mathrm{W}$ & $549-271$ & 1142 & Weddell Sea \\
\hline PS124_94-5 & SFT & 08.03 .2021 & $22: 34$ & $01: 51$ & $77^{\circ} 02.489^{\prime} \mathrm{S}$ & $034^{\circ} 44.773^{\prime} \mathrm{W}$ & $77^{\circ} 02.090^{\prime} \mathrm{S}$ & $034^{\circ} 35.713^{\prime} \mathrm{W}$ & $776-781$ & 670 & Weddell Sea \\
\hline PS124_101-1 & NFT & 11.03 .2021 & $23: 16$ & $03: 37$ & $74^{\circ} 53.368^{\prime} \mathrm{S}$ & $030^{\circ} 45.606^{\prime} \mathrm{W}$ & $74^{\circ} 51.349^{\prime} \mathrm{S}$ & $030^{\circ} 41.046^{\prime} \mathrm{W}$ & $509-497$ & 1188 & Fishnest \\
\hline PS124_107-5 & EFS & 12.03 .2021 & $02: 12$ & $03: 54$ & $75^{\circ} 03.582^{\prime} \mathrm{S}$ & $026^{\circ} 44.742^{\prime} \mathrm{W}$ & $75^{\circ} 03.397^{\prime} \mathrm{S}$ & $026^{\circ} 39.718^{\prime} \mathrm{W}$ & $291-349$ & 355 & Weddell Sea \\
\hline
\end{tabular}

